\title{
Primary Diffuse Large B-Cell Lymphoma of the Breast
}

\section{: A Rare Case Report and Review of the Literature}

\author{
Bamidele J. Alegbeleye ${ }^{1 *}$ and Olorunseun 0. Ogunwobi ${ }^{2}$ \\ ${ }^{1}$ Department of Surgery, St Elizabeth Catholic General Hospital \& Cardiac Center, Shisong P.O Box 8, \\ Kumbo-Nso, Northwestern Region, Cameroon
}

${ }^{2}$ Hunter College Center for Cancer Health Disparities Research, Department of Biological Sciences, Hunter College of The City University of New York, New York, NY 10065, USA

E-mail: oo158@hunter.cuny.edu

*Corresponding author details: Dr. Bamidele J. Alegbeleye, drbalegbeleye@gmail.com

\begin{abstract}
BACKGROUND: Breast lymphomas are rare extranodal lymphomas. They constitute a tiny percentage of malignant tumors of the breast and a small subset of extranodal lymphomas. The rarity of breast lymphomas is attributed to the very scanty lymphoid tissue content of the chest wall.

AIMS OF STUDY: This case report aims to provide an up-to-date review of the literature on breast lymphomas and clinicians to consider the possibility of this disease entity while treating a breast mass.

CASE PRESENTATION: A case is reported of primary mammary non-Hodgkin lymphoma in a 52-year-old man. Fine needle aspiration cytology (FNAC) was inconclusive. Incisional biopsy-confirmed primary breast lymphoma was diagnosed as the diffuse large B-cell type: non - Hodgkin lymphoma. He had complete disease remission in response to chemotherapy - Cyclophosphamide, Doxorubicin, Vincristine, and Prednisolone (CHOP). After that, the patient did not require further surgical intervention. He was followed up at two-monthly intervals for eighteen months in the surgical outpatient clinic with no disease recurrence and satisfactory clinical outcome, following which he discontinued follow-up visits.

CONCLUSION: While assessing breast masses, clinicians must recognize primary non-Hodgkin lymphoma as a potential differential diagnosis. A core biopsy of breast masses is needed to exclude it, and appropriate treatment must be given if diagnosed.
\end{abstract}

Keywords: non-hodgkin lymphoma; primary breast lymphoma; diffuse large B-cell lymphoma; breast cancer; combination chemotherapy

\begin{abstract}
ABBREVIATIONS
PBL: Primary breast lymphoma; NHL: Non-Hodgkin lymphoma; DLBCL: Diffuse large B - cell lymphomas; PNHL: Primary -non-Hodgkin lymphoma; SBL: Secondary breast lymphoma; MALT: mucosal-associated lymphoid tissue; IELSG: International Extranodal Lymphoma Study Group; CXCL12 and CXCL13: cellular receptors and tissue chemo-attractants; GCB: Germinal center B cell subtypes; Non-GCB: Non-Germinal center B cell subtypes; ABC: Activated B cell subtypes; PFS: Progression-free survival; OS: overall survival; PB-DLBCL: Primary breast- Diffuse large B - cell lymphomas; IPI: International prognostic index; CISL: Consortium for improving the survival of lymphoma; OED: one extranodal disease; MED: multiple extranodal diseases
\end{abstract}

\section{INTRODUCTION}

Primary breast lymphoma (PBL) is a rare clinical entity but a well-defined subtype of non-Hodgkin lymphoma (NHL). Several reports suggest that PBL is uncommon, representing only $0.5 \%$ of malignant breast tumors, $1 \%$ of all NHL, and 2\% of extranodal lymphomas [1-5]. Most breast lymphomas are non-Hodgkin's type, which represents approximately 70-90\% [6]. Diffuse large B - cell lymphomas (DLBCL) constitute $46-71 \%$ of all PBL [7].
However, primary NHL (PNHL) is the most frequent hematopoietic tumor of the breast $[8,9]$.

\section{Definition of Terms}

Breast lymphoma has been classified into primary and secondary types. PBL is described as the co-existence of lymphoid infiltrate and mammary tissues at the same site, and in the absence of evident widespread lymphoma or other extra-mammary lymphomas [10-12]. On the contrary, secondary breast lymphoma (SBL), therefore, is a clinical scenario in which the breast has lymphoid infiltrate, in addition to the presence of other extramammary sites of lymphoma. The clear difference between PBL and SBL is sometimes tricky and, in some cases, not readily distinguished $[13,14]$. Interestingly, there are also other less frequent NHL subtypes, including mucosal-associated lymphoid tissue (MALT) lymphoma, follicular lymphoma, Burkitt's lymphoma, and T-cell lymphoma [1, 2, 15-17]. In 1972, Wiseman and Liao [18] redefined PBL according to four criteria that are summarized in Table 1 below. They include (i) mammary tissue and lymphoma must be in close anatomic proximity, (ii) no preceding diagnosis of extra-mammary lymphoma, (iii) no evidence of disseminated disease, 
other than ipsilateral axillary lymphadenopathy, and (iv) adequate quality of the histopathological specimen.

\section{Pathogenesis of Breast Lymphomas}

The pathogenesis of breast lymphomas is still not wholly known. However, the documented evidence of what is known might suggest different pathogenesis for PBL. One study on PB-DLBCL conducted by the International Extranodal Lymphoma Study Group (IELSG), revealed that about $40 \%$ of relapses were initially in the breast [3]. A related study by the same group regarding testicular lymphoma revealed an ipsilateral and contralateral relapse rate of only $20 \%$ [21].

The phenomenon of 'organ-specific relapse' might reflect poor local disease control but also brings to mind the possibility likelihood of homing of tissue. This phenomenon may be mediated by cellular receptors and tissue chemo-attractants such as CXCL12 and CXCL13, as reported in other extranodal lymphomas [22].

\section{Sub-classifications of DLBCL}

There has been progressing in the area of gene expression profiling and immunohistochemistry. On this basis, DLBCL is now being characterized as germinal center $B$ cell (GCB) and activated $B$ cell $(\mathrm{ABC} /$ non-GCB) subtypes, with the latter having a more unsatisfactory outcome [23-25]. Only a few studies have examined this sub-classification in PBL, but results are fascinating. Niitsu et al. [26] mentioned that a nonGCB pattern in $57 \%$ of PB-DLBCL found in their study confirmed a poor progression-free survival (PFS); but, not representative of the overall survival (OS).

Furthermore, Yhim et al. [27] performed a comparison of PBL and nodal DLBCL and reported significantly higher rates of non-GCB in PBL (95\% versus 62\%, $\mathrm{P}<0.001$ ), with similar 3year OS and PFS rates as the GCB cohort [27].

\section{Lymphoma and Sex Hormones}

While the overwhelming majority of patients with PBL are females, there are a few rare reports in males [3, 28-33]. These distinct gender differences suggest that sex hormones may be necessary for the pathogenesis of PBL. Further evidence in support of the likely involvement of sex hormones is the relatively high rate $(5 \%-20 \%)$ of bilateral disease at diagnosis $[3,14,34]$. The latest effort has been geared towards establishing a possible link between lymphoma, estrogen, and prolactin, which has also come from in vitro and epidemiological studies. Still, the results remain inconclusive [35-40]. Only two reports are referring to sex hormone expression in human PBL tissue. Ariad et al. [41] examined eleven PBL specimens, none of which stained positively for estrogen receptor (ER). At the same time, Hugh et al. [42] reported ER positivity in two PBL tissue specimens. Therefore, there may be a link between sex hormones and the development of NHL in general and PBL in particular. However, further research is required to establish the role of sex hormones in PBL.

\section{Systemic B Symptoms and DLBCL}

Reviews of the data from large clinical trials of DLBCL reveal that about $25 \%-37 \%$ of these patients have systemic symptoms [43-45]. However, in 26 publications on PBL, the range was usually between $0 \%$ and $22 \%$, suggesting a low prevalence of systemic B symptoms $[1-5,13,21,28,46-58]$. Moreover, using the Wiseman-Liao criteria [18], patients with systemic involvement are not part of the original definition resulting in the pre-selection of patients with the locoregional disease and reduced chances of developing $B$ symptoms. Taken together with the lymphoma international prognostic index (IPI), the prevalence of systemic B symptoms in the vast majority of PBL patients is low to the intermediate-range [18].

\section{Clinical Considerations}

The clinical presentation and radiological features of PBL are similar to those of breast carcinoma. PBL is mostly observed in females with scarce documentation of cases in males. In most patients, the most common presentation is a painless enlarging breast mass. Patients with PBL often present with signs of skin edema, retraction, erythema, and nipple involvement. On a mammogram, breast lymphomas may lack the irregular borders of infiltrating carcinomas, and more than half the tumors exhibit no calcification $[59,60]$.

Notwithstanding the clinical and radiographic similarities between the two tumor types, their treatments differ radically. Routine fine needle aspiration cytology (FNAC) reveals diagnosis in most cases performed for breast lumps, but sometimes it is inconclusive as with the current evidence that was originally misdiagnosed as poorly differentiated duct carcinoma [61,62]. Hence, it is essential to accurately distinguish lymphomas from other breast malignancies to assign patients to treatment appropriately. However, no clear consensus about the treatment of PBL has emerged. Therefore, the accumulation of data in the form of case reports and other clinical studies is essential $[63,64]$.

\section{Staging and Prognostication}

Prognostic indicators include the clinical stage, histologic type, and patient's age [12]. In clinical practice, the Wiseman-Liao definition confirms the clinical phase of PBL to Ann Arbor IE or IIE, and patients are by definition 'early-stage' [18]. The significant difference between stages IE and IIE (involvement of regional lymph nodes) is vital because of variation with stage IIE (20\%-57\%) $[20,46,54,65]$. In this respect, the use of positron emission tomography (PET) scan becomes relevant to better mark the stages due to its high sensitivity in DLBCL. There is a lack of data on PB-DLBCL, yet from the few cases described, it seems that PET yields similar advantages as in nodal DLBCL $[66,67]$. Bilateral PBL is rare, and both staging and prognostication are controversial. The most extensive series of PB-DLBCL reported until now, classified cases with bilateral breast involvement as stage IV [3], whereas others have defined them as stage IE [47] or II [46, 49, 53, 54, 68, 69]. For the sake of uniformity, and given a possible worse prognosis of bilateral PBL $[2,4,42,47,70]$, these rare cases may well be classified as stage IV disease. The stratification of PBL into risk groups is usually based upon the international prognostic index (IPI) [71]. Several reports have suggested alternative models for PBL prognostication, identifying increased microvascular density or increased levels of soluble interleukin-2 receptors $(>1000 \mathrm{U} / \mathrm{ml})$ [26] as predictors of worse outcome [46]. "The report by the Consortium for improving the survival of lymphoma (CISL) summarized 68 cases of PB-DLBCL; from the existing definition of one extranodal disease (OED) category when one breast was involved and multiple extranodal diseases (MED) when additional extranodal sites are present" [2]. In both types, the presence of nodal disease was not seen as relevant. The OED group had better 5-year PFS than the MED group (64.9\% versus $27.5 \%$, respectively) and better 5 year OS (74.3\% versus $24.5 \%$, respectively) [2]. Further, tumor dimension has been noted by several investigators as vital, with a size of $4-5 \mathrm{~cm}$ possibly predicting worse outcome [12, 16, 26, 47, 65]. This cutoff is probably derived from the breast TNM classification, which defines tumor size $>5 \quad \mathrm{~cm}$ as 
being the largest diameter of interest [72]. "Analysis of available data on the outcome of PBDLBCL (Table 2), and comparison with nodal DLBCL, has led us to the conclusion that both categories have a similar prognosis as long as all patients are treated primarily with anthracycline-containing regimens followed by radiotherapy" [11].

In addition to the above, there is growing interest in an in-depth database of breast lymphomas in general. Many reports suggest that "the breast is an unfavorable primary site and that this lymphoma group displays a relatively poorer prognosis than other localized lymphomas" [18, 20, 70].

\section{AIMS OF STUDY}

This case report aims to provide an up-to-date review of the literature on breast lymphomas and encourage clinicians to consider the possibility of this disease entity whenever they manage a patient with a breast mass.

\section{CASE PRESENTATION}

A 52-year-old male industrial chemist presented to the surgical outpatients' department at a tertiary hospital, with a painless left breast lump of 8 months duration, which increased in size progressively. There was darkish skin discoloration but no nipple discharge. The patient also had significant weight loss and intermittent fever over the 8 months period. The patient had no family history of cancer. He initially received herbal medications for some months and was only presented to the tertiary hospital due to herbal medications' failure. Physical examination revealed a middle-aged man who was chronically-ill looking and cachectic. The left breast was diffusely enlarged with a $4 \mathrm{~cm} \times 3 \mathrm{~cm}$ size mass in the central portion with a darkening of overlying skin. Also, he had discrete tiny ulcers in the nipple-areolar complex oozing very scanty serosanguinous fluid. Axillary lymph nodes and other lymph node fields were unremarkable, as was the remainder of his physical examination.

FNAC was suspicious of malignancy but inconclusive. He subsequently had an incisional biopsy with histopathological analysis, which confirmed PBL diagnosed with a large B-cell type (non-Hodgkin lymphoma). The clinical photograph of this patient is as displayed in Figure 1. Figure 2 shows the characteristic diffuse lesion, as seen in the mammographic study, and Figure 3 shows DLBCL with activated B cell type. The tumor cells were negative for CD3, CD5, CD15, CD30, CD45, and cytokeratin (CK) pan but were positive for CD20, CD10, and BCL6, as seen in Figures 4 to 7. The breast scan showed multiple heteroechoic tiny masses of variable sizes in the central portion of the right breast. Cranial and abdominal computed tomography (CT) scans were mainly typical. However, a chest CT scan showed left pulmonary infiltrates with hilar lymphadenopathy but no pleural effusion. The biochemical profile and complete blood count were also standard. Subsequently, the patient had six courses of chemotherapy courses Cyclophosphamide, Doxorubicin, Vincristine, and Prednisolone (CHOP). Interestingly, the patient did not require further surgical intervention. He had complete disease remission and was followed up at two-monthly intervals for eighteen months in the surgical outpatient clinic with no disease recurrence and satisfactory clinical outcome, following which he discontinued follow-up visits.

\section{DISCUSSION}

We are here reporting the case of a male patient with a lesion involving the left breast. While "both nodal and extranodal lymphomas are slightly predominant in males, breast involvement is seen mostly in females" [73]. Thus, our report is rare. "Some have previously reported that cases of PNHL of the breast involve the right breast and that almost all affected patients are females" [7, 8]. Primary breast lymphomas are generally regarded as rare, but they remain the most frequent hematopoietic tumor of the breast $[6-9,59]$. Clinicians treating breast carcinomas should be aware of this entity to distinguish its clinical presentation, management, and prognosis from breast carcinoma $[6,10-12]$. Single-breast involvement is more common, particularly in the upper quadrant of the right side [74-77].

Interestingly, $1 \%$ to $14 \%$ of reported PBL cases have bilateral disease [20]. Many criteria have been formulated for the diagnosis of primary lymphoma of the breast [77]. In 1972, Wiseman and Liao defined diagnostic criteria for PNHL of the breast to include 1) the presence of technically adequate pathologic specimens, 2) the close association of mammary tissue, 3) lymphomatous infiltrate, 4) no prior diagnosis of extramammary lymphoma and 5) possible ipsilateral axillary lymph nodes involvement $[8,77-80]$. The patient we are reporting on fulfilled these criteria, which further supports our conclusion that this was a case of primary breast lymphoma. PBL and breast cancers, in general, are not the disease of the younger age group. There is a slight preference for the right breast, but the explanation remains unclear [81]. It presents most commonly as a palpable mass, as seen in this patient $[82,83]$.

Open biopsy supported with immunophenotyping proved to be a very reliable confirmatory diagnostic tool in this case. Tru-cut biopsies have equally established the diagnosis of breast malignancies with a very high accuracy rate $[84,85]$. Radiographic examinations, including mammography, sonography, and CT, are generally nonspecific for PBL [86-89]. Immunophenotyping in the diagnosis of PNHL of the breast is very important. Several reports in the literature confirm that immunophenotyping continues to be the key in evaluating these patients [42, 90-96]. In this case, we are reporting; the histopathological diagnosis was PBL of the large B-cell type (non Hodgkin type). Tumor cells were negative for CD3, CD5, CD15, CD30, CD45, and CK but were positive for CD20, CD10, and BCL6. There was clinical evidence of distant metastasis to the lung parenchyma (T2 N0 M1).

Several treatment options are available for PBL: surgery, radiation, and chemotherapy have been used alone or in combination. The most common therapeutic approach is chemotherapy with or without adjuvant radiotherapy [64, 95-97]. The impact of surgery in PBL treatment is restricted to obtaining adequate tissue for accurate diagnosis and classification, PBL treatment is similar to that for lymphomas at other sites [94, 95], mastectomy offers no survival benefit or protection from recurrence [14]. In patients with PBL, the survival rates are comparable to those with other lymphomas in general. They are highly favorable when compared to the survival rates of those with breast carcinoma. Prognosis depends on the histological tumor grade $[18,70,94]$. Predictors of survival according to the International Prognostic Index include 1) age, 2) LDH levels, 3) performance status, 4) Ann Arbor staging, and 5) the presence of extranodal tumors in predicting the 5-year survival $[95,96]$. For stage I disease, the 5-year survey is $89 \%$ [97]. 
The central nervous system is regarded as the most common site of relapse from available reports $[98,99]$.

\section{CONCLUSION}

In conclusion, clinicians are encouraged to assess breast masses carefully and perform core biopsy to determine if the breast mass is PBL and then give appropriate treatment.

\section{DECLARATIONS}

\section{ACKNOWLEDGMENTS:}

Many thanks to the Consortium of Pathologists who provided support for the Immunohistochemistry-study FUNDING: This case report has not been granted any financial assistance from the public, or non-public sources declared

\section{AVAILABILITY OF DATA AND MATERIALS:}

Not Applicable

DISCLOSURES: Olorunseun O. Ogunwobi is supported by National Cancer Institute grant \# U54 CA221704, and is Co-Founder of NucleoBio, Inc, a City University of New York start-up biotechnology company.

AUTHORS'CONTRIBUTIONS: The authors did the conception, design, coordination, drafting, reading, and approval of the final manuscript

ETHICAL APPROVAL: Ethical approval is not required for case reports at St Elizabeth Catholic General Hospital \& Cardiac Center, Cameroon.

CONSENT FOR PUBLICATION: A written informed consent was obtained from the patient for publication of this case report and any accompanying images.

COMPETING INTERESTS: None declared

\section{REFERENCES}

[1] Validire P, Capovilla M, Asselain B, Kirova Y, Goudefroye R, Plancher C et al. Primary breast non-Hodgkin's lymphoma: a large single center study of initial characteristics, natural history, and prognostic factors. Am J Hematol 2009; 84: 133139

[2] Yhim HY, Kang HJ, Choi YH, Kim SJ, Kim WS, Chae YS et al. Clinical outcomes and prognostic factors in patients with breast diffuse large B cell lymphoma; Consortium for Improving Survival of Lymphoma (CISL) study. BMC Cancer 2010; 10: 321.

[3] Ryan G, Martinelli G, Kuper-Hommel M, Tsang R, Pruneri G, Yuen K et al. Primary diffuse large B-cell lymphoma of the breast: prognostic factors and outcomes of a study by the International Extranodal Lymphoma Study Group. Ann Oncol 2008; 19: 233-241.

[4] Talwalkar SS, Miranda RN, Valbuena JR, Routbort MJ, Martin AW, Medeiros LJ et al. Lymphomas involving the breast: a study of 106cases comparing localized and disseminated neoplasms. Am J Surg Pathol 2008; 32: 1299-1309

[5] Fruchart C, Denoux Y, Chasle J, Peny AM, Boute V, Ollivier JM et al. High grade primary breast lymphoma: is it a different clinical entity? Breast Cancer Res Treat 2005; 93: 191-198

[6] Nigam A, Singh AK, Singh SK, Singh N. Primary Mammary (Non-Hodgkin) Lymphoma of Breast: A Case Report. J Cancer Sci Ther, 3, 2011, 173-5.

[7] Pullen CM, Cass AJ. Bilateral primary lymphoma of the breast. Aust N Z J Surg, 66, 2000, 845-7.

[8] Jeon HJ, Akagi T, Hoshida Y, Hayashi K, Yoshino T. Primary non-Hodgkin malignant lymphoma of the breast. An immunohistochemical study of seven patients with breast lymphoma in Japan. Cancer, 70, 1992, 2451-59.

[9] Khan AS, Bakshi GD, Patel KK, Borse HG, Sankaye $\mathrm{PB}$, Bhan-darkar LD. Primary non-Hodgkin's lymphoma of the breast. Bombay Hosp J 2002;44: 481-482

[10] Jabbour G, El-Mabrok G, Al-Thani H, El-Menyar A, Al- Hijji I, Napaki S: Primary Breast Lymphoma in a Woman: A Case Report and Review of the Literature. Am J Case Rep. 2016; 17: 97-103.

[11] Aviv A, Tadmor T, Polliack A. Primary diffuse large B-cell lymphoma of the breast: looking at pathogenesis, clinical issues and therapeutic options. Annals of Oncology 2013; 24: 2236-2244.

[12] Uesato M, Miyazawa Y, Gunji Y, Ochiai T. Primary non-Hodgkin lymphoma of the breast: report of a case with special reference to 380 cases in the Japanese literature. Breast Cancer, 12, 2005, 154-8.

[13] Sabate JMGA, Gómez A, Torrubia S, Camins A, Roson N, De Las Heras P et al. Lymphoma of the breast: clinical and radiological features with pathologic correlation in 28 patients. Breast J 2002; 8: 294-304.

[14] Arber DA SJ, Weiss LM, Rappaport H. NonHodgkin's lymphoma involving the breast. Am J Surg Pathol 1994; 18: 288-295.

[15] Avenia N, Sanguinetti A, Cirocchi R, Bistoni G, Trastulli S, D'Ajello F et al. Primary breast lymphomas: a multi centric experience. World J Surg Oncol 2010; 8: 53-57.

[16] Martinelli G, Ryan G, Seymour JF, Nassi L, Steffanoni S, Alietti A et al. Primary follicular and marginal-zone lymphoma of the breast: clinical features, prognostic factors and outcome: a study by the international extra nodal lymphoma study group. Ann Oncol 2009; 20: 1993-1999.

[17] Guo HY ZX, Li J, Hu XC. Primary non-Hodgkin's lymphoma of the breast: eight-year follow-up experience. Int J Hematol 2008; 87: 491-497.

[18] Wiseman C, Liao KT. Primary lymphoma of the breast. Cancer 1972; 29: 1705-1712.

[19] Gholam D, Bibeau F, El Weshi A, Bosq J, Ribrag V et al. Primary breast lymphoma. Leuk Lymphoma 2003; 44: 1173-1178.

[20] Jennings WC, Baker RS, Murray SS, Howard CA, Parker DE, Peabody LF et al. Primary breast lymphoma: the role of mastectomy and the importance of lymph node status. Ann Surg 2007; 245: 784-789.

[21] Zucca E, Conconi A, Mughal TI, Sarris AH, Seymour $\mathrm{JF}$, Vitolo $\mathrm{U}$ et al. Patterns of outcome and prognostic factors in primary large-cell lymphoma of the testis in a survey by the International Extra nodal Lymphoma Study Group. J Clin Oncol 2003; 21: 20-27.

[22] Pals ST, de Gorter DJ, Spaargaren M. Lymphoma dissemination: the other face of lymphocyte homing. Blood 2007; 110: 3102-3111.

[23] Rosenwald A, Wright G, Chan WC, Connors JM, Campo E, Fisher RI et al. The use of molecular profiling to predict survival after chemotherapy for diffuse large-B-cell lymphoma. N Engl J Med 2002; 346: 1937-1947.

[24] Lenz G, Wright G, Dave SS, Xiao W, Powell J, Zhao H et al. Stromal gene signatures in large-B-cell lymphomas. N Engl J Med2008; 359: 2313-2323.

[25] Hans CP, Weisenburger DD, Greiner TC, Gascoyne RD, Delabie J, Ott G et al. Confirmation of the molecular classification of diffuse large B-cell lymphoma by immunohistochemistry using a tissue microarray. Blood 2004; 103: 275-282.

[26] Niitsu N, Okamoto M, Nakamine H, Hirano M et al. Clinicopathologic features and treatment outcome of primary breast diffuse large B-cell lymphoma. Leuk Res 2008; 32: 1837-1841. 
[27] Yhim HY, Kim JS, Kang HJ, Kim SJ, Kim WS, Choi $\mathrm{CW}$ et al. Matched-pair analysis comparing the outcomes of primary breast and nodal diffuse large B-cell lymphoma in patients treated with rituximab plus chemotherapy. Int J Cancer 2012; 131: 235243.

[28] Cao YB WS, Huang HQ, Xu GC et al. Primary breast lymphoma-a report of 27 cases with literature review. Chinese J Cancer 2007; 26: 89-89

[29] Mouna B, Saber B, Tijani EH, Hind M, Amina T, Hassan E. Primary malignant non-Hodgkin's lymphoma of the breast: a study of seven cases and literature review. World J Surg Oncol 2012; 10: 151-156.

[30] Rathod J, Taori K, Disawal A, Gour P, Dhakate S, Mone $\mathrm{R}$ et al. A rare case of male primary breast lymphoma. J Breast Cancer 2011; 14: 333-336.

[31] Duman BB, Sahin B, Guvenc B et al. Lymphoma of the breast in a male patient. MedOncol 2011; 28(Suppl. 1): S490-493.

[32] Mpallas G, Simatos G, Tasidou A et al. Primary breast lymphoma in a male patient. Breast 2004; 13: 436-438.

[33] Ko ES, Seol H, Shin JH, Ko EY. Primary anaplastic lymphoma kinase-negative anaplastic large-cell lymphoma of the breast in a male patient. $\mathrm{Br} \mathrm{J}$ Radiol 2012; 85: e79-e82.

[34] Meerkotter D, Rubin G, Joske F, Angunawela P, Khalafallah A et al. Primary breast lymphoma: a rare entity. J Radiol Case Rep 2011; 5: 1-9.

[35] Shim GJ, Gherman D, Kim HJ, Omoto Y, Iwase H, Bouton D et al. Differential expression of oestrogen receptors in human secondary lymphoid tissues. J Pathol 2006; 208: 408-414.

[36] Yakimchuk K, Iravani M, Hasni MS, Rhönnstad P, Nilsson S, Jondal $\mathrm{M}$ et al. Effect of ligand-activated estrogen receptor beta on lymphoma growth in vitro and in vivo. Leukemia 2011; 25: 1103-1110.

[37] Singh MP, Sharma H, Singh SM. Prolactin promotes growth of a spontaneous $\mathrm{T}$ cell lymphoma: role of tumor and host derived cytokines. Cancer Invest 2006; 24: 601-610.

[38] Bishop JD, Nien WL, Dauphinee SM, Too CKL et al. Prolactin activates mammalian target of-rapamycin through phosphatidylinositol 3-kinaseand stimulates phosphorylation of p70S6Kand 4Ebinding protein-1 in lymphoma cells. J Endocrinol 2006; 190: 307-312.

[39] Hooghe R, Merchav S, Gaidano G, Naessens F, Matera $\mathrm{L}$ et al. A role for growth hormone and prolactin in leukaemia and lymphoma? Cell Mol Life Sci 1998; 54: 1095-1101.

[40] Skibola CF, Bracci PM, Paynter RA, Forrest MS, Agana $\mathrm{L}$, Woodage $\mathrm{T}$ et al. Polymorphisms and haplotypes in the cytochrome P450 17A1, prolactin, and catechol-0-methyltransferase genes and non-Hodgkin lymphoma risk. Cancer Epidemiol Biomarkers Prev 2005; 14: 2391-2401.

[41] Ariad S, Lewis D, Cohen R, Bezwoda WR. Breast lymphoma. A clinical and pathological review and 10-year treatment results. S Afr Med J 1995; 85: 85-89.

[42] Hugh JC, Jackson FI, Hanson J, Poppema S. Primary breast lymphoma. An immunohistologic study of 20 new cases. Cancer 1990; 66: 2602-2611.

[43] Pfreundschuh M, Schubert J, Ziepert M Schmits R, Mohren M, Lengfelder E. Six versus eight cycles of bi-weekly CHOP-14 with or without rituximab in elderly patients with aggressive CD20+Bcell lymphomas: a randomized controlled trial (RICOVER-60). Lancet Oncol 2008; 9: 105-116.
[44] Coiffier B, Lepage E, Briere J, Herbrecht R, Tilly H, Bouabdallah $\mathrm{R}$ et al. CHOP chemotherapy plus rituximab compared with CHOP alone in elderly patients with diffuse large-B-cell lymphoma. N Engl J Med 2002; 346: 235-242.

[45] Pfreundschuh M, Trumper L, Osterborg A, Pettengell R, Trneny M, Imrie K et al. CHOP-like chemotherapy plus rituximab versus CHOP-like chemotherapy alone in young patients with good prognosis diffuse large-B-cell lymphoma: a randomized controlled trial by the Mab Thera International Trial (MInT) Group. Lancet Oncol 2006; 7: 379-391.

[46] ZhaoS, Zhang QY, Ma WJ, Zhang MH, Sun WZ, Li HB et al. Analysis of 31 cases of primary breast lymphoma: the effect of nodal involvement and microvascular density. Clin Lymphoma Myeloma Leuk 2011; 11: 33-37.

[47] Fukuhara S, Watanabe T, Munakata W, Mori M, Maruyama D, Kim SW et al. Bulky disease has an impact on outcomes in primary diffuse large B-cell lymphoma of the breast: a retrospective analysis at a single institution. Eur J Haematol 2011; 87: 434440.

[48] Ganjoo K, Advani R, Mariappan MR, McMillan A, Horning $\mathrm{S}$ et al. Non-Hodgkin lymphoma of the breast. Cancer 2007; 110: 25-30.

[49] Julen 0, Dellacasa I, Pelte MF et al. Primary breast lymphomas. Rare Tumors 2009; 1: e14.

[50] Seker M, Bilici A, Ustaalioglu BO, Yilmaz B, Ozturk B, Unal A et al. Clinicopathologic features of the nine patients with primary diffuse large $B$ cell lymphoma of the breast. Arch Gynecol Obstet 2011; 284: 405-409.

[51] Barista I, Baltali E, Tekuzman G, Kars A, Ruacan S, Ozisik Y et al. Primary breast lymphomas-a retrospective analysis of twelve cases. Acta Oncol 2000; 39: 135-139.

[52] Giardini R, Piccolo C, Rilke F. Primary nonHodgkin's lymphomas of the female breast. Cancer 1992; 69: 725-735.

[53] Smith MR, Brustein S, Straus DJ. Localized nonHodgkin's lymphoma of the breast. Cancer 1987; 59: 351-354.

[54] Wong WW, Schild SE, Halyard MY, Schomberg PJ et al. Primary non-Hodgkin lymphoma of the breast: the Mayo Clinic Experience. J Surg Oncol 2002; 80: 19-25. Discussion26.

[55] Park YH, Kim SH, Choi SJ, Ryoo BY, Kang YK, Lee SS et al. Primary malignant lymphoma of the breast: clinic-pathological study of nine cases. Leuk Lymphoma2004; 45: 327-330.

[56] Ha CS, Dubey P, Goyal LK et al. Localized primary non-Hodgkin lymphoma of the breast. Am J Clin Oncol 1998; 21: 376-380.

[57] Caon J, Wai ES, Hart J Alexander C, Truong PT, Sehn LH et al. Treatment and outcomes of primary breast lymphoma. Clin Breast Cancer 2012; 12: 412-419.

[58] Salzberg MP MJ, Press OW, Habermann TM et al. Primary Breast Diffuse Large B Cell Lymphoma: A Distinct Clinical Entity. In American Society of Hematology Annual Meeting, Atlanta, GA 2012.

[59] Kelten C, Kabukcu S, Sen N et al. Secondary involvement of the breast in T-cell non-Hodgkin lymphoma, an unusual example mimicking inflammatory breast carcinoma. Arch Gynecol Obstet. 2009;280: 149-152

[60] Jackson FI, Lalani ZH. Breast lymphoma: radiologie imaging and clinical appearances. Can Assoc Radialj 1991:48-54. 
[61] Pope Tl Jr, Brenbridge ANAG, Sloop FB Jr, et al. Primary histiocytic lymphoma of the breast: mammographie, sonographic and pathologic correlation. J Clin Ultrasound 1985; 13: 667-670.

[62] Anuradha, Sinha A, Ramrakhiani D: Primary nonHodgkin's lymphoma of the breast: a case report. Acta Cytol 2005, 49:661-665.

[63] Duncan VE, Reddy VV, Jhala NC, Chhierng DC, Jhala DN: Non-Hodgkin's lymphoma of the breast: a review of 18 primary and secondary cases. Ann Diagn Pathol 2006, 10:144-148.

[64] Aviles A, Delgado S, Nambo MJ, Neri N, Murillo E, Cleto S: Primary breast lymphoma: results of a controlled clinical trial. Oncology2005, 69:256-260.

[65] Jeanneret-Sozzi W, Taghian A, Epelbaum R Poortmans P, Zwahlen D, Amsler B et al. Primary breast lymphoma: patient profile, outcome and prognostic factors. A multicenter Rare Cancer Network study. BMC Cancer 2008; 8: 86-92.

[66] Yang WT, Lane DL, Le-Petross HT, Abruzzo LV, Macapinlac HA. Breast lymphoma: imaging findings of 32 tumors in 27 patients. Radiology 2007; 245: 692-702.

[67] Santra A, Kumar R, Reddy R et al. FDG PET-CT in the management of primary breast lymphoma. Clin Nucl Med 2009; 34: 848-853.

[68] Yi JI, Chae BJ, Bae JS et al. Bilateral primary breast lymphoma. Chin Med J (Engl) 2010; 123: 14821484.

[69] Suzuki Y, Tokuda Y, Okumura A, Saito Y, Ohta M, Kubota $\mathrm{M}$ et al. Three cases of malignant lymphoma of the breast. Japanese J Clin Oncol 2000; 30: 3336.

[70] Ryan GF, Roos DR, Seymour JF. Primary nonHodgkin's lymphoma of the breast: retrospective analysis of prognosis and patterns of failure in two Australian centers. Clin Lymphoma Myeloma 2006; 6: 337-341.

[71] Project TIN-HsLPF. A predictive model for aggressive non-Hodgkin's lymphoma. The International Non-Hodgkin's Lymphoma Prognostic Factors Project. N Engl J Med 1993; 329 : 987-994.

[72] Singletary SE, Allred C, Ashley P, Bassett LW, Berry $\mathrm{D}$, Bland $\mathrm{KI}$ et al. Revision of the American Joint Committee on Cancer staging system for breast cancer. J Clin Oncol 2002; 20: 3628-3636.

[73] Chan WC, Weiss LM, Schnitzer B: Lymp nodes. In Anderson's Pathology. Tenth edition. Edited by I Damjanov, J Linder, AS Patterson. St Louis, Mosby, 1996, pp 1115-1200

[74] Yang H, Lang R-G, Fu L. Primary breast lymphoma (PBL): A literature review. Clin Oncol Cancer Res. 2011; 8:128-132.

[75] Inic Z, Inic M, Zegarac M, Inic I, Pupic G . Three cases of combined therapy in primary breast lymphoma (PBL) with successful outcomes. Clin Med Insights Oncol. 2013;7:159-63.[PMC free article] [PubMed]

[76] Garg NK, Bagul NB, Rubin G, Shah EF. Primary lymphoma of the breast involving both axillae with bilateral breast carcinoma. World J Surg Oncol. 2008;6:52.[PMC free article] [PubMed]

[77] Gualco G, Chioato L, Harrington WJ Jr, Weiss LM, Bacchi CE. Primary and secondary T-cell lymphomas of the breast: clinico-pathologic features of 11 cases. Appl Immunohistochem Mol Morphol, 2009; 17: 301-306

[78] Kebudı A, Coban A, Yetkın G, Tanik C, Uludag M, Akgun I et al. Primary T-lymphoma of the breast with bilateral involvement, unusual presentation. Int J Clin Pract, 2005; 59: 95-98 (PMID: 15875638)
[79] Cohen FL, Brooks JJ: Lymphomas of the breast. Cancer 1991; 67: 1359- 1369

[80] Bobrow LG, Richards MA, Happerfield LC: Breast lymphoma. Hum Pathol 1993; 24: 274-278

[81] Lawler MR, Richie RE: Reticulum cell sarcoma of the breast. Cancer 1967; 20: 1438- 1446

[82] Carter TR, Feldman PS, Innes DJ, Henry F, Frigy AF: The role of fine needle aspiration cytology in the diagnosis of lymphoma. Acta Cytol 1988; 32: 848853

[83] Brogi E. Harris NL. Lymphoma of the breast; Pathology and clinical behavior. Semin Oncol 1999; 26: 357-364

[84] Shery LW, Ramzy I: Analysis of false positive results in a series of 835 FNA of breast lesions. Acta Cytol. 1995;39: 858-864

[85] Wilkinson EJ, Schuettke CM, Ferrier CM, Franzini DA, Bland KI. Fine needle aspiration of breast masses: An analysis of 276 aspirates. Acta cytol 1989; 33: 613-619

[86] Oya M, Hirahashi M, Ochi M, Hashimoto $M$, Ohshima K, Kikuchi $M$ et al. Spontaneous regression of primary breast lymphoma. Pathol Int 2009; 59: 664-669. (PMID: 19712136)

[87] Ogawa T, Tsuji EI, Shirakawa K, et al. Primary nonHodgkin's lymphoma of the breast treated nonsurgically: report of three cases. Breast Cancer2009; 7. (PMID: 19350354)

[88] Maounis N, Ellina E, Papadaki T, et al. Bilateral primary lymphoma of the breast: a case report initially diagnosed by FNAC. Diagn Cytopathol 2005; 32: 114-118. (PMID: 15637680)

[89] Loughrey MB, Windrum P, Catherwood MA, et al. WHO reclassification of breast lymphomas. Clin Pathol 2004; 57: 1213-1214. (PMID:15509687)

[90] Aguilera NS, Tavassoli FA, Chu WS, Abbondanzo SL. T-cell lymphoma presenting in the breast: a histologic, immunophenotypic and molecular genetic study of four cases. Mod Pathol2000; 13 : 599-605. (PMID: 10874662)

[91] Kopans DB, Swann AA, White G, et al. Asymmetric breast tissue Radiology 1989;171: 639-643.

[92] Mettler FA, Guiberteau MJ. Tumor and inflammation imaging. Essentials of nuclear medicine imaging, 3rd ed. Philadelphia: W.B. Saunders; 1991:253-267

[93] Sokolov T, Shimnov M, Blickstein D, Nobel M, Antebi E: Primary lymphoma of the Breast: An unusual presentation of breast cancer. Eur J Surg 2000; 166: 390-393

[94] Baker R, Slayden G, Jennings W: Multifocal primary breast lymphoma. South Med J 2005, 98:10451048.

[95] Babovic N, Jelic S, Jovanovic V: Primary nonHodgkin lymphoma of the breast: is it possible to avoid mastectomy? J Exp Clin Cancer Res 2000, 19:149-154.

[96] Mason HS, Johari V, March DE, Crisi GM: Primary breast lymphoma: radiologic and pathologic findings. Breast J 2005, 11:495-496.

[97] Choo SP, Lim ST, Wong EH, Tao M: Breast lymphoma: favorable prognosis after treatment with standard combination chemotherapy. Oncology 2006, 29:14-18.

[98] Coffey J, Hodgson DC, Gospodarowicz MK: Therapy of non-Hodgkin's lymphoma. Eur J Nucl Mol Imaging 2003, 30(Suppl.1):28-36

[99] Anania G, Baccarani U, Risaliti A, et al. Primary non-Hodgkin's T-cell lymphoma of the breast. Eur J Surg, 1997; 163: 633-635. (PMID:9298918) 
TABLE 1: WISEMAN AND LIAO CRITERIA FOR PBL [18]

\begin{tabular}{|l|l|}
\hline 1 & Mammary tissue and lymphoma must be in close anatomic proximity \\
\hline 2 & No preceding diagnosis of extra-mammary lymphoma \\
3 & No evidence of disseminated disease, other than ipsilateral axillary lymphadenopathy, and \\
4 & Adequate quality of the histopathological specimen \\
\hline 5 & These criteria are widely accepted in general $[3,12,15,16,19,20]$ \\
\hline
\end{tabular}

TABLE 2: TREATMENT MODALITIES AND OUTCOME IN SELECTED SERIES OF PBL BASED ON WHO CLASSIFICATIONS

\begin{tabular}{|c|c|c|c|c|c|c|c|c|c|}
\hline \multirow[b]{2}{*}{ AUTHORS } & \multirow[b]{2}{*}{$\mathbf{N}$} & \multirow[b]{2}{*}{$\begin{array}{c}\% \\
\text { <INT-IPI }\end{array}$} & \multicolumn{4}{|c|}{ TREATMENT MODALITY } & \multicolumn{2}{|c|}{ OUTCOME } & \multirow[b]{2}{*}{ REFERENCE } \\
\hline & & & $\begin{array}{l}\text { CHOP } \\
\text { N (\%) }\end{array}$ & $\begin{array}{c}\text { RITUXIMAB } \\
\text { N (\%) }\end{array}$ & $\begin{array}{c}\text { RADIATION } \\
\mathrm{N} \quad(\%) \\
\end{array}$ & $\begin{array}{c}\text { SURGERY } \\
\text { N (\%) } \\
\end{array}$ & $\begin{array}{l}\% \\
\text { CR }\end{array}$ & $\begin{array}{c}\% \\
\text { 5YEAR } \\
\text { OS } \\
\end{array}$ & \\
\hline $\begin{array}{l}\text { Kuper } \\
\text { Hommel }\end{array}$ & 38 & 71 & $13(34)$ & 0 & $21(55)$ & $26(68)$ & 68 & 45 & 71 \\
\hline Fruchart & 19 & 100 & $11(58)$ & 0 & $15(79)$ & $4(21)$ & 84 & 73 & 05 \\
\hline Yoshida & 15 & NR & $12(80)$ & 0 & NR & $11(73)$ & NR & NR & 24 \\
\hline Aviles & 96 & NR & $66(69)$ & 0 & $64(67)$ & $\mathrm{NR}$ & 72 & 58 & 69 \\
\hline Cao & 27 & 100 & $25(93)$ & $1(4)$ & $5(19)$ & $8(30)$ & 89 & 47 & 17 \\
\hline Ganjoo & 37 & $78^{a}$ & $17(46)$ & $7(19)$ & $14(38)$ & NR & 88 & 82 & 47 \\
\hline Aviles & 32 & 100 & $32(100)$ & $32(100)$ & $32(100)$ & NR & 87 & NR & 70 \\
\hline Niitsu & 30 & 100 & $32(100)$ & $11(37)$ & $18(60)$ & NR & 97 & 87 & 26 \\
\hline Ryan & 204 & $78^{a}$ & $143(70)$ & NR & $130(64)$ & $100(49)$ & 89 & 63 & 03 \\
\hline Lin & 23 & NR & NR & $2(9)$ & $15(65)$ & $5(22)$ & 100 & 81 & 18 \\
\hline Julen & 7 & NR & $2(29)$ & 0 & $1(14)$ & $7(100)$ & 71 & 51 & 48 \\
\hline Validire & 38 & 65 & $36(95)$ & $4(10)$ & $27(71)$ & NR & 89 & 61 & 1 \\
\hline Yhim & 68 & 76.5 & $66(97)$ & $42(62)$ & 21(31) & $23(34)$ & 83 & 60 & 2 \\
\hline Zhao & 31 & NR & $21(68)$ & $6(29)$ & $30(97)$ & $31(100)$ & NR & 71 & 45 \\
\hline Seker & 9 & 100 & $8(89)$ & $7(78)$ & $5(56)$ & 0 & 67 & 76 & 49 \\
\hline Fukuhara & 14 & 93 & $13(93)$ & $7(50)$ & $9(64)$ & $4(29)$ & 93 & 76 & 46 \\
\hline Mouna & 7 & 86 & $6(86)$ & $2(29)$ & $2(29)$ & $4(57)$ & 71 & NR & 28 \\
\hline Salzberg & 75 & 69 & $68(91)$ & $52(69)$ & $51(68)$ & NR & NR & 75 & 57 \\
\hline Caon & 34 & NR & $28(82)$ & $12(35)$ & $17(50)$ & $4(12)$ & 76 & 54 & 56 \\
\hline TOTAL & 804 & & $597(74)$ & $182(23)$ & 477(59) & $227(28)$ & & & \\
\hline
\end{tabular}

Abbreviation in Table

NR= Not Reported

Int. IPI= Intermediate risk international prognostic index

$\mathbf{X}^{\mathbf{a}}=$ Percentage of patients in whom IPI was available

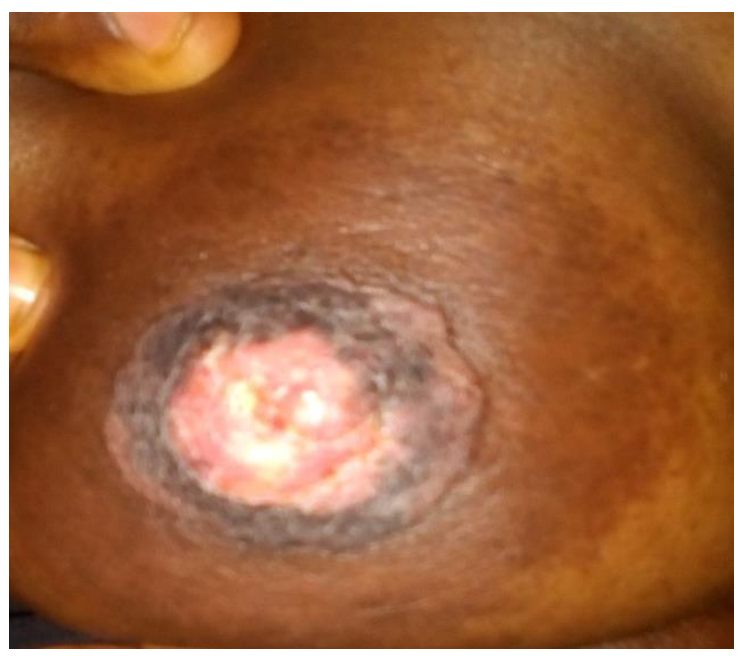

FIGURE 1: THE INDEX PATIENT

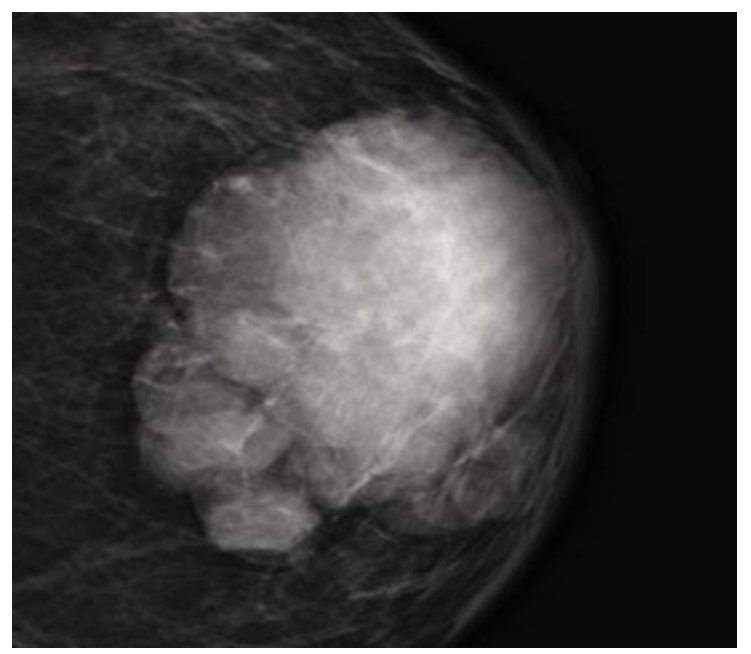

FIGURE 2: DIFFUSE RIGHT BREAST LESION 


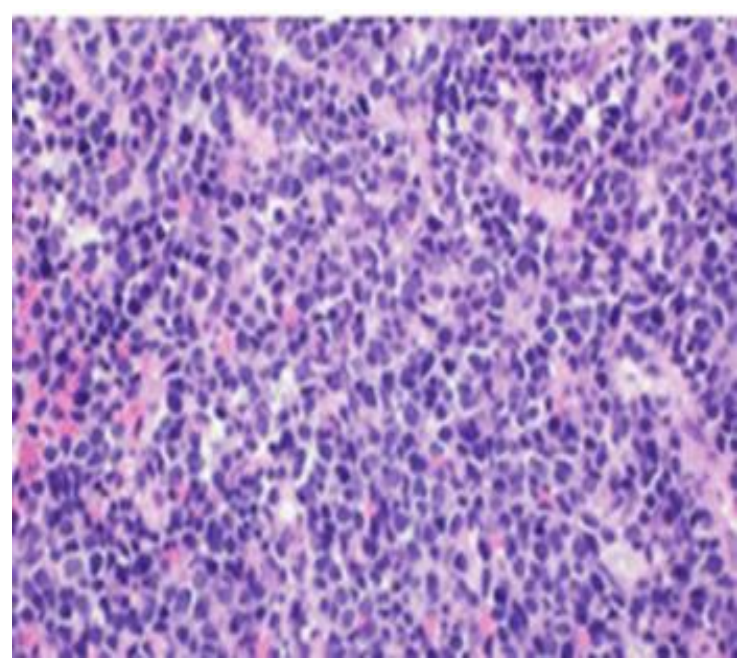

FIGURE 3: H\&E STAIN, X400

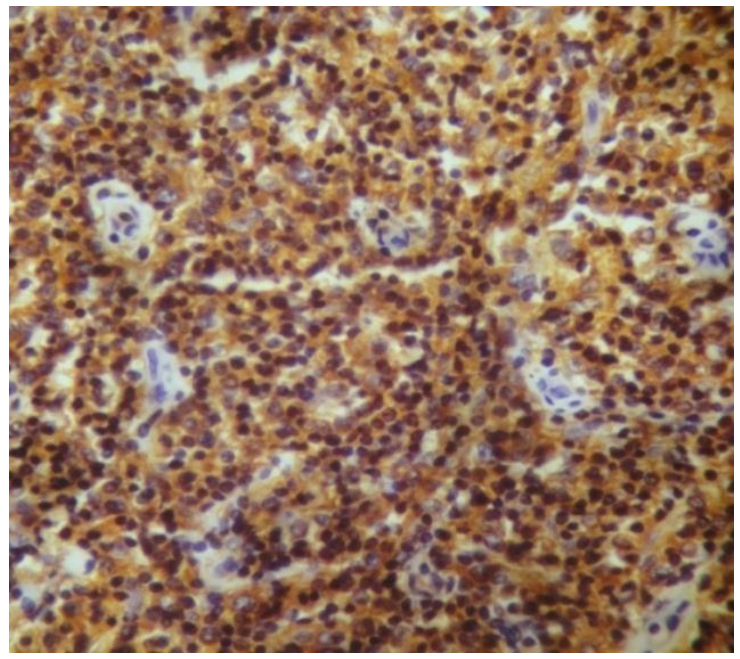

FIGURE 5: CD 45

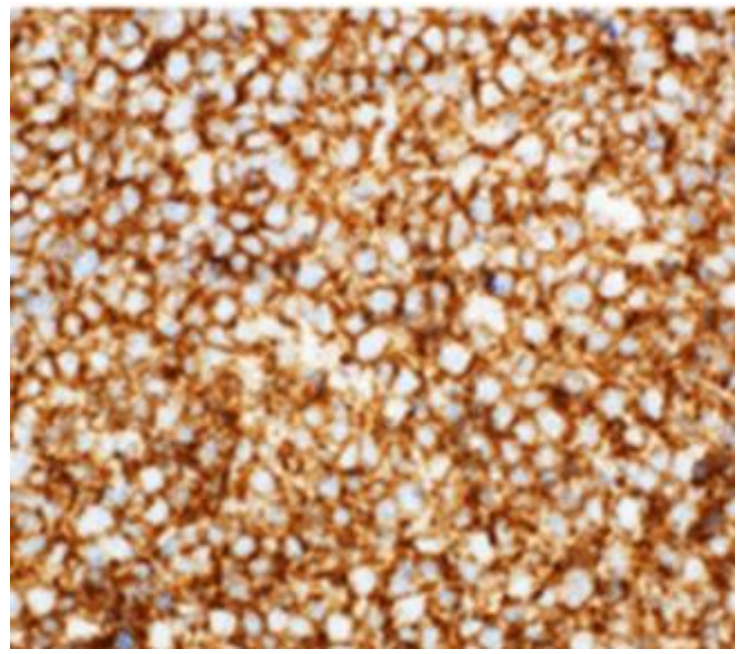

FIGURE 7: CD 10

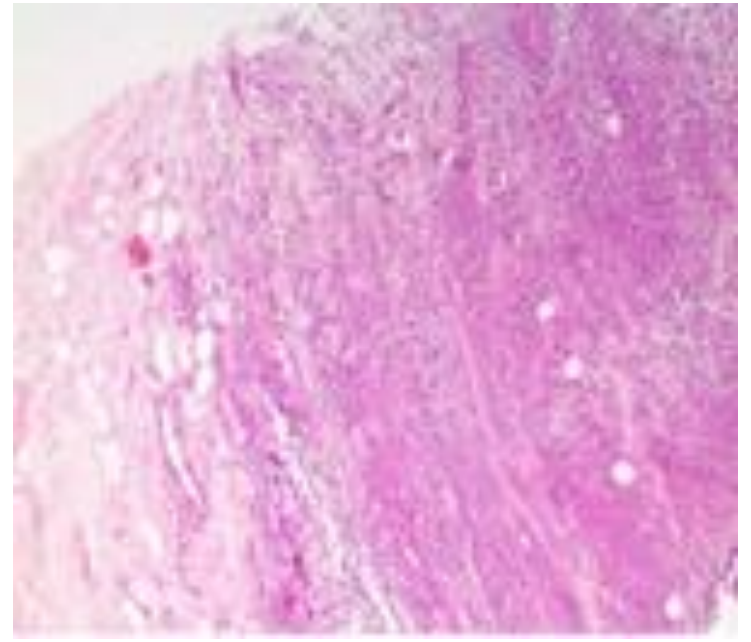

FIGURE 4: DLBCL WITH ACTIVATED B CELL TYPE

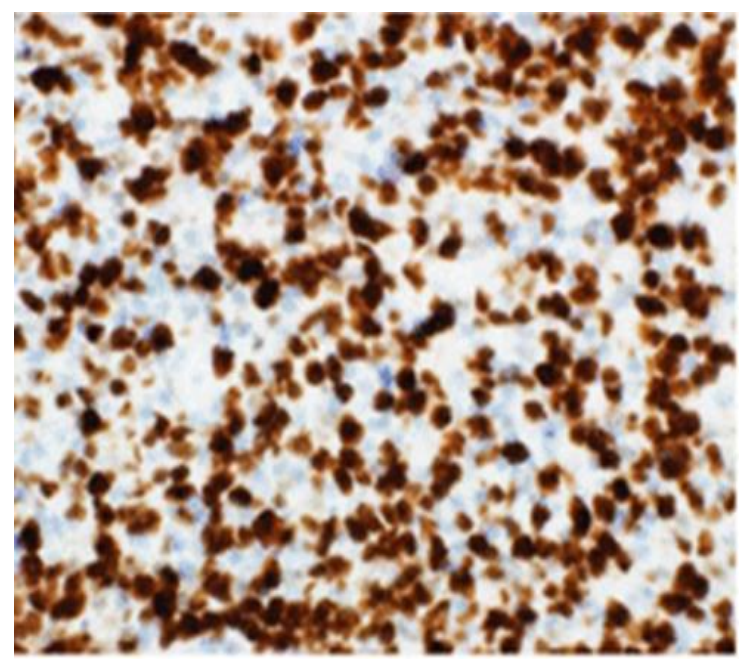

FIGURE 6: CD 20

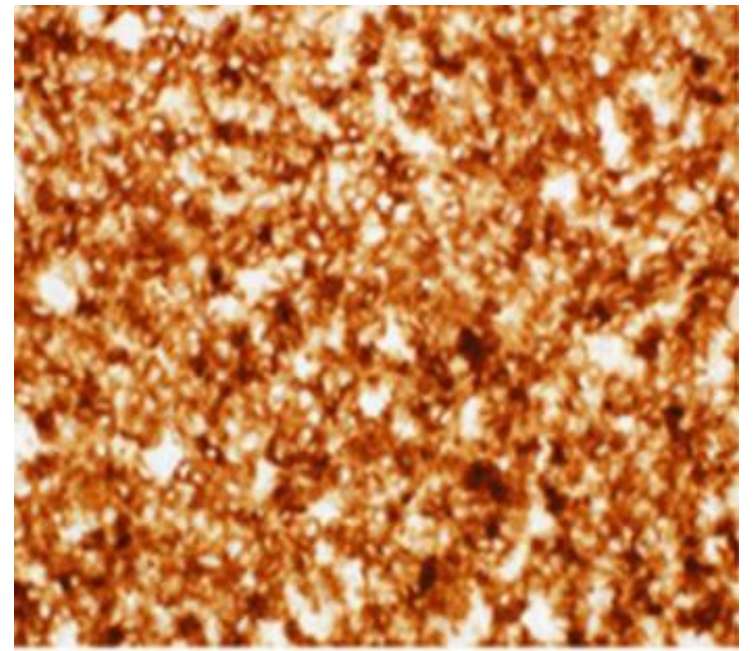

FIGURE 8: BCL6+ (UNCOMMON) 